\title{
9. BACTERIAL PROFILES IN DEEP SEDIMENT LAYERS FROM THE LAU BASIN (SITE 834) ${ }^{1}$
}

\author{
B.A. $\mathrm{Cragg}^{2}$
}

\begin{abstract}
Sediment samples, to a depth of $104 \mathrm{~m}$ below the seafloor (mbsf), from an area of low oceanic productivity were examined for the presence of bacteria. Bacterial cells were observed at all depths, and dividing cells were observed in 29 out of 32 samples. When compared with equivalent bacterial counts made on sediment samples from the Peru Margin and the Japan Sea (areas of high oceanic productivity), total counts were lower at the sediment near-surface in absolute terms $\left(6.12 \times 10^{8} \mathrm{cells} / \mathrm{cm}^{3}\right)$ and decreased with depth two to nine times faster, reaching $3.31 \times 10^{6} \mathrm{cells} / \mathrm{cm}^{3}$ at $104.4 \mathrm{mbsf}$. Numbers of dividing cells were very similar to counts obtained at other sites at the sediment near-surface $\left(9.74 \times 10^{7} \mathrm{cells} / \mathrm{cm}^{3}\right)$ but decreased with depth some five times faster than in high productivity sites to reach $5.61 \times 10^{5} \mathrm{cells} / \mathrm{cm}^{3}$ at $97.3 \mathrm{mbsf}$.
\end{abstract}

\section{INTRODUCTION}

Sediment bacteria are intimately involved in both the degradation and preservation of organic matter within marine sediments, and they play a major role in the global biogeochemical cycling of the elements (Jørgensen, 1983). The importance of bacterial activity within surface sediments is well recognized (Sørensen, 1978; Sørensen and Jørgensen, 1987); however, it is only more recently that their occurrence in deeper sediment layers has become more widely accepted. Geochemical evidence has suggested, indirectly, that bacteria are active to considerable depths (Krumbein, 1983); furthermore, because bacteria can grow in excess of $100^{\circ} \mathrm{C}$ (Jannasch and Taylor, 1984), temperature is unlikely to limit bacterial growth until depths of several kilometers.

Early evidence of the presence of deep sediment bacteria (Rittenberg, 1940; ZoBell, 1958; Davis, 1967) was based solely on the enrichment of viable bacteria. With this technique, a high potential for contamination of the deep sediment layers by the more active surface sediments exists. Recent publications have reported the cultivation of bacteria, using more rigorous techniques, from depths of $200 \mathrm{mbsf}$ (Oremland et al., 1982; Belyaev and Ivanov, 1983; Bianchi, 1986); and work in deep aquifers (White et al., 1983; Erlich and Ghiorse, 1989; Balkwill, 1989; Phelps et al., 1989; Chapelle and Lovley, 1990; Fredrickson et al., 1991) has demonstrated the presence of bacteria in sediments over $400 \mathrm{mbsf}$. Data from the marine environment is very limited, however. Evidence for low levels of bacterially mediated sulfate reduction and methanogenesis between 4 and 167 mbsf has been found in sediments from the Gulf of Mexico and the New Jersey area of the North Atlantic (Whelan et al., 1985; Tarafa et al., 1987). In a comprehensive study of sediments from the Peru Margin, Cragg et al. (1990) and Parkes et al. (1990) reported substantial numbers of bacteria associated with significant levels of sulfate reduction and methanogenesis to $80 \mathrm{mbsf}$. Most recently, investigation of sediments from the Japan Sea has established the occurrence and activity of bacteria to over 500 mbsf (Cragg et al., 1992; Getliff et al., 1992).

The sediment samples from the Peru Margin and the Japan Sea were both from zones of high oceanic productivity, with consequent high organic matter inputs to the sediments. It is not known how globally representative the bacterial depth distributions obtained from these organically rich sediments are, compared with sediments from areas of relatively low oceanic productivity. Areas of low productivity represent by far the greatest proportion of the world's oceans. Sediment core samples from Leg 135 in the Lau Basin were obtained to

\footnotetext{
' Hawkins, J., Parson, L., Allan, J., et al., 1994. Proc. ODP, Sci. Results, 135: College Station, TX (Ocean Drilling Program).

${ }^{2}$ Department of Geology, University of Bristol, Bristol BS8 IRJ, United Kingdom.
}

determine the presence, concentration, and depth distribution of bacteria in a sediment from a low oceanic productivity zone.

\section{MATERIALS AND METHODS Shipboard Handling}

A linear series of sediment samples was removed from 32 sections, between 0 and $104.4 \mathrm{mbsf}$, of Hole 834A (Table 1). During recovery of the first core, a significant amount of loose, flocculant, surficial sediment was displaced as the corer penetrated the sediment; thus, the sample from $0 \mathrm{mbsf}$ is more properly defined as near-surface. Evidence from pollen analyses of the cores taken in the Japan Sea suggested that some $60 \mathrm{~cm}$ was lost from the top of the first core (L. Heusser, pers. comm., 1991). Immediately after a core was cut into $1.5-\mathrm{m}$ sections on the outside catwalk, a thin layer of sediment was removed from the section end using a sterile scalpel to expose an uncontaminated surface. A $2-\mathrm{cm}^{3}$ sample was then taken with a sterile (autoclaved) 5-mL syringe from which the leur end had been removed. The sample was divided into two pieces, with $1 \mathrm{~cm}^{3}$ being ejected directly into a tared serum vial containing $9 \mathrm{~mL}$ of filter sterilized $(0.2 \mu \mathrm{m}) 4 \%$ formaldehyde in artificial seawater and the second $1 \mathrm{~cm}^{3}$ into a glass sample vial for wet/dry weight determination.

\section{Laboratory Handling}

\section{Direct Microscopic Observations}

Acridine orange staining and microscopic observations were based on the general recommendations of Fry (1988). Fixed samples were vortex mixed, and a $4-10 \mu \mathrm{L}$ subsample was added to $10 \mathrm{~mL}$ of $2 \%$ filter sterilized $(0.1 \mu \mathrm{m})$ formaldehyde in artificial seawater. Acridine orange $(50 \mu \mathrm{L})$ was added to give a final concentration of $5 \mathrm{mg} / \mathrm{dm}^{3}$. After $3 \mathrm{~min}$ the solution was filtered through a $25-\mathrm{mm}$ Nucleopore black polycarbonate membrane (Appleton Woods, Birmingham, U.K.) of $0.2-\mu \mathrm{m}$ pore size. The filter was rinsed with a further $10 \mathrm{~mL}$ of $2 \%$ filter sterilized formaldehyde in artificial seawater and mounted in a minimum of paraffin oil under a coverslip. Two replicate filters were prepared from each sample to minimize the variance of the counts (Kirchman et al., 1982). Where replicate $\log _{10}$ counts differed by more than $0.5 \log$ units, a third replicate filter was prepared. A minimum of 200 fields of view were counted.

The mounted membrane filters were viewed under incident illumination with a Zeiss Axioskop microscope fitted with a 50-W mercury vapor lamp, a wide-band interference filter set for blue excitation, a $100 \times$ (numerical aperture $=1.3$ ) Plan Neofluar objective lens, and $10 \times$ eyepieces. Bacterially shaped green and red fluorescing objects were counted. Cells on or off particles were counted separately, and the numbers of those on particles doubled in the final calculations to 
Table 1. Detailed list of Hole 834A samples provided for direct bacterial counts.

\begin{tabular}{cr}
\hline $\begin{array}{c}\text { Core, section, } \\
\text { interval (cm) }\end{array}$ & $\begin{array}{r}\text { Depth } \\
\text { (mbsf) }\end{array}$ \\
\hline $135-834 \mathrm{~A}-$ & \\
& \\
$1 \mathrm{H}-1,0-1$ & 0.00 \\
$1 \mathrm{H}-3,0-1$ & 3.00 \\
$1 \mathrm{H}-5,0-1$ & 6.00 \\
$2 \mathrm{H}-2,0-1$ & 9.10 \\
$2 \mathrm{H}-4,0-1$ & 12.10 \\
$2 \mathrm{H}-6,0-1$ & 15.10 \\
$3 \mathrm{H}-2,0-1$ & 18.60 \\
$3 \mathrm{H}-4,0-1$ & 21.60 \\
$3 \mathrm{H}-6,0-1$ & 24.60 \\
$4 \mathrm{H}-2,0-1$ & 28.10 \\
$4 \mathrm{H}-4,0-1$ & 31.10 \\
$4 \mathrm{H}-6,0-1$ & 34.10 \\
$5 \mathrm{H}-2,0-1$ & 37.60 \\
$5 \mathrm{H}-4,0-1$ & 40.60 \\
$5 \mathrm{H}-6,0-1$ & 43.60 \\
$6 \mathrm{H}-2,0-1$ & 47.10 \\
$6 \mathrm{H}-4,0-1$ & 50.10 \\
$6 \mathrm{H}-6,0-1$ & 53.10 \\
$7 \mathrm{H}-2,0-1$ & 56.60 \\
$7 \mathrm{H}-4,0-1$ & 59.60 \\
$7 \mathrm{H}-6,0-1$ & 62.60 \\
$8 \mathrm{H}-2,0-1$ & 66.10 \\
$8 \mathrm{H}-4,0-1$ & 69.10 \\
$8 \mathrm{H}-6,0-1$ & 72.10 \\
$9 \mathrm{H}-2,0-1$ & 75.60 \\
$9 \mathrm{H}-4,0-1$ & 78.60 \\
$9 \mathrm{H}-6,0-1$ & 81.60 \\
$10 \mathrm{X}-2,0-1$ & 85.10 \\
$10 \mathrm{X}-3,140-141$ & 88.00 \\
$11 \mathrm{X}-2,0-1$ & 94.70 \\
$11 \mathrm{X}-3,109-110$ & 97.29 \\
$12 \mathrm{X}-2,0-1$ & 104.40 \\
\hline & \\
\hline
\end{tabular}

Note: Site 834 is located in the Lau Basin at $18^{\circ} 34.08^{\prime} \mathrm{S}$, $177^{\circ} 51.72^{\prime} \mathrm{E}$.

account for cells hidden from view by particles (Goulder, 1977). Dividing cells (those with a clear invagination) and divided cells (pairs of cells of identical morphology) were also counted. The detection limit was calculated to be $1 \times 10^{5}$ cells $/ \mathrm{cm}^{3}$.

\section{Porosity and Organic Matter}

Sediment wet/dry weight ratios and porosity were obtained by drying the tared $1 \mathrm{~cm}^{3}$ of sediment to constant weight at $105^{\circ} \mathrm{C}$. Organic matter content was estimated by heating subsamples of dried sediment in a muffle furnace at $450^{\circ} \mathrm{C}$ to constant weight. After the sample had been destructively treated for this measurement, a small random error detected in the balance made the data unreliable. These data were discarded, therefore, and the more limited shipboard data were used where necessary.

\section{RESULTS AND DISCUSSION}

Bacteria were present in all samples to $104.4 \mathrm{mbsf}$ (Fig. 1). A rapid decline occurred in numbers from the near-surface $\left(6.12 \times 10^{8}\right.$ cells/ $\left.\mathrm{cm}^{3}\right)$ to $21.6 \mathrm{mbsf}\left(1.65 \times 10^{7}\right.$ cells $\left./ \mathrm{cm}^{3}\right)$, representing a 37 -fold decrease. Thereafter, the numbers declined more slowly to $3.31 \times 10^{6}$ cells $/ \mathrm{cm}^{3}$ at $104.4 \mathrm{mbsf}$, a further 5 -fold decrease. The lowest count made was at $69.1 \mathrm{mbsf}$ with $2.39 \times 10^{6}$ cells $/ \mathrm{cm}^{3}$, reflecting a 255 -fold decrease on the near-surface count. The other depth interval notable for a particularly low value, compared with adjacent depth intervals, was $62.6 \mathrm{mbsf}$ (Fig. 1). Both these samples contained significant amounts of black vitric ash and were the only 2 of the 32 samples investigated to do so.

The actual numbers of bacterial cells counted on the filter membranes were very low, averaging 0.4 cells per field of view over all

\section{$\log _{10}$ cell numbers $/ \mathrm{cm}^{3}$}

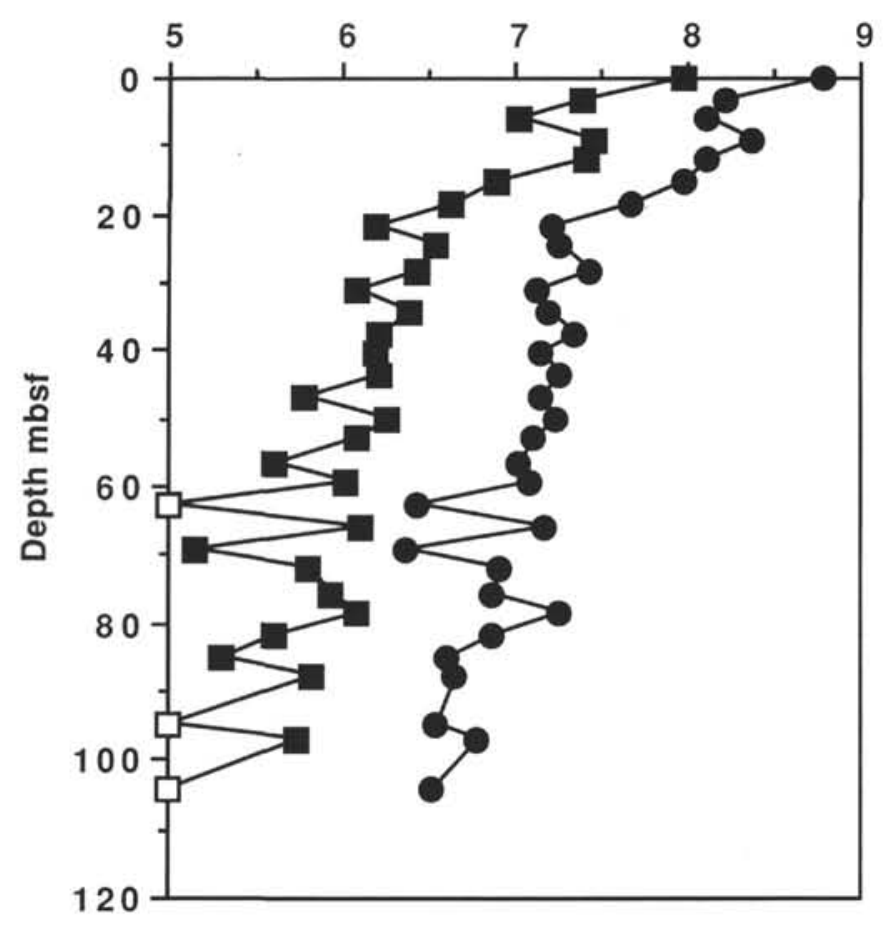

Figure 1. Depth distribution of total bacteria (solid circles) and dividing cells (solid squares), using the Acridine Orange Direct Count (AODC) technique, to 104.4 mbsf in Hole 834A. Open symbols indicate a zero count at the detection limit of $1 \times 10^{5}$ cells $/ \mathrm{cm}^{3}$.

32 samples. Where fewer than 25 bacteria were counted per field, a dramatic increase in the coefficient of variation can occur (Kirchman et al., 1982), although Fry (1988) considers 10 bacteria per field of view to be acceptable. Kirchman et al. (1982) based these limits on counts made on 7-10 fields of view; however, when the number of fields is increased, the coefficient of variation decreases. The bacterial numbers for this site were obtained from counts of more than 200 fields per subsample, giving a total number of cells counted approaching that deemed acceptable by Fry (1988). Analysis of the results by paired sample $t$-test showed no significant difference between total count replicates $(t=1.35, N=32, P<0.15)$. In addition, the mean and $95 \%$ confidence limits for the difference between the $\log _{10}$ total count replicates was $0.358 \pm 0.12 \mathrm{log}$ units, respectively. Therefore, the data are thought to be both valid and reproducible estimates of the total bacterial population.

When compared with total counts made at other ODP sites, the near-surface values are considerably lower than those from more productive sites (Table $2 \mathrm{~A}$ ), representing approximately $78 \%$ of that from Leg 128 and $57 \%$ of that from Leg 112 . The near-surface count for Leg 112 is $1.47 \mathrm{~m}$ below that for the other two sites; however, data obtained from the sediment surface at the same site during a separate cruise gave a count of $3.29 \times 10^{9}$ at $0.03 \mathrm{mbsf}$ (B.A. Cragg, J.C. Fry, J.M. Getliff, and R.J. Parkes, unpubl. data, 1989). This reduces the Leg 135 data as a percentage of Leg 112 to $19 \%$.

Comparison of the bacterial depth profile with those from Legs 112 and 128 is only possible to 80.2 mbsf, as this was the deepest sample from the Leg 112 site (Cragg et al., 1990). The rate of decrease in cell numbers with depth is much greater than that observed in Legs 112 and 128 (Table 2A). Even using the unpublished data given above, the Leg 112 percentage reduction on near-surface count changes from $31 \%$ to $10.7 \%$, a figure still some nine times greater than that in Leg 135. It is likely that these differences in the bacterial profiles with 
sediment depth are related to both the productivity of the overlying water column and the water depth at each site (Table 2). In general, bacterial depth distributions will be positively related to water column productivity in that the higher the productivity, the greater the quantity of organic matter sinking to the sediment surface. Any changes in this productivity over depositional time scales will be reflected at specific sediment depths. Conversely, water depth should be negatively related in that the further organic matter has to sink, the lower the quantity and quality on reaching the sediment as only the more recalcitrant, less bioavailable carbon will escape microbial degradation during sinking (Jørgensen, 1983; Gooday and Turley, 1990; Turley and Lochte, 1990). The average organic carbon value for Leg 135 is sufficiently low to be considered unreliable at approximately $0.2 \%$ (Parson, Hawkins, Allan, et al., 1992) compared with $2.2 \%$ for Leg 128 (Ingle, Suyehiro, von Breymann, et al., 1990), and $2.7 \%$ for Leg 112 (Suess, von Huene, et al., 1986; ten Haven et al., 1990) over the same depth range. In addition, the differences in bioavailability of this material will be much greater than suggested by these differences in concentration (Parkes and Buckingham, 1986).

Dividing cells were observed at all depths except $62.6,94.7$, and 104.4 mbsf (Fig. 1). The profile again demonstrated two distinct phases, however; dividing cell numbers initially decreased at a significantly faster rate than the total counts. Between the sediment near-surface and $21.6 \mathrm{mbsf}$, a 63 -fold reduction from $9.74 \times 10^{7}$ cells $/ \mathrm{cm}^{3}$ to $1.55 \times 10^{6} \mathrm{cells} / \mathrm{cm}^{3}$ took place; thereafter, the decline was more gradual to $5.61 \times 10^{5}$ cells $/ \mathrm{cm}^{3}$ at $97.3 \mathrm{mbsf}$, representing a further 2.5 -fold decrease. The lowest positive count of dividing cells was made at $69.1 \mathrm{mbsf}$ with $1.45 \times 10^{5} \mathrm{cells} / \mathrm{cm}^{3}$, reflecting a 670 -fold reduction of the near-surface count. The actual numbers of dividing cells counted on the filters were small, representing approximately $10 \%$ of the total cell count over all. This will certainly increase the variability of the data (Kirchman et al., 1982), and the dividing cell data set is indeed more irregular than that of the total cell counts (Fig. 1). Nevertheless, the trend of decreasing numbers of dividing cells with depth is obvious.

A comparison of numbers of dividing cells at the near-surface with data from Legs 112 and 128 (Table 2B) shows them to be very similar, at an average of $8.3 \times 10^{7}$ cells $/ \mathrm{cm}^{3}$ (this remains true even when substituting the unpublished data for Leg 112). Despite this, the decrease in dividing cells observed in Leg 135 samples is substantially faster (approximately five-fold) than that in either of Legs 112 or 128. Again, this may well be linked to the lack of available organic carbon in the sediment.

The dividing cell profile significantly correlates with that of the total count $(R=0.970, N=32, P<0.002)$. This close relationship was observed at other sites (Cragg et al., 1990, 1992). The numbers of bacteria involved in cell division (9.4\% mean and $0-17.4$ range) are higher than observed in sediments from more productive areas, such as the Japan Sea (4.8\% mean and 0.5-12.3 range; Cragg et al., 1992) or from the Peru Margin (4.2\% mean and 0-8.9 range; B.A. Cragg, J.C. Fry, J.M. Getliff, and R.J. Parkes, unpubl. data, 1989). It is certainly true that the counts made below 50 mbsf were close to the detection limit of $1 \times 10^{5}$ cells $/ \mathrm{cm}^{3}$ (Fig. 1), which therefore increased variability. However, as the highest dividing cell counts were from the upper $50 \mathrm{~m}$ ( $11.5 \%$ mean and 6.7-17.4 range), where the data were more reliable, counting near the detection limit may not totally explain the high average percentages. This unlikely apparent inverse relationship between dividing cell numbers and oceanic productivity requires much more data to establish, but it does indicate a need for careful interpretation of dividing cell data from sediments to obtain a better understanding of the environmental controls on deep sediment bacteria. Bacterially mediated sulfate reduction and methanogenesis were not directly measured at this site; however, no microbially related porewater gradients were present. The interstitial sulfate depth profile was relatively constant, with an average downhole concentration of 27.8 $\mathrm{mM}$, approximating that of seawater, and dissolved methane concentrations consistently at or below the detection limit of 2-3 ppm. In addition, alkalinity levels were low, decreasing slightly from $3 \mathrm{mM}$ at
Table 2. Comparison of direct bacterial count data from three ODP legs.

\begin{tabular}{|c|c|c|c|}
\hline \multirow[b]{2}{*}{ Overiying water depth (m) } & \multicolumn{3}{|c|}{$\begin{array}{c}\text { Cells } / \mathrm{cm}^{3} \\
\text { Decreasing oceanic productivity }\end{array}$} \\
\hline & $\begin{array}{c}\text { Leg 112-Peru } \\
\text { Hole } 681 \mathrm{C} \\
252\end{array}$ & $\begin{array}{c}\text { Leg 128-Japan } \\
\text { Hole 798B } \\
900\end{array}$ & $\begin{array}{c}\text { Leg 135-Lau } \\
\text { Hole } 834 \mathrm{~A} \\
2692\end{array}$ \\
\hline A. Near-surface & $\begin{array}{c}(1.50 \mathrm{mbsf}) \\
1.06 \times 10^{9}\end{array}$ & $\begin{array}{c}(0.03 \mathrm{mbsf}) \\
7.82 \times 10^{8}\end{array}$ & $\begin{array}{c}(0.03 \mathrm{mbsf}) \\
6.12 \times 10^{8}\end{array}$ \\
\hline Approximately $80 \mathrm{mbsf}$ & $\begin{array}{c}(80.20 \mathrm{mbsf}) \\
3.33 \times 10^{8}\end{array}$ & $\begin{array}{c}(78.89 \mathrm{mbsf}) \\
1.71 \times 10^{7}\end{array}$ & $\begin{array}{c}(81.60 \mathrm{mbsf}) \\
7.50 \times 10^{6}\end{array}$ \\
\hline Near-surface count (\%) & $31 \%$ & $2.2 \%$ & $1.2 \%$ \\
\hline B. Near-surface & $\begin{array}{l}(1.50 \mathrm{mbsf}) \\
8.84 \times 10^{7}\end{array}$ & $\begin{array}{l}(0.03 \mathrm{mbsf}) \\
6.35 \times 10^{7}\end{array}$ & $\begin{array}{l}(0.03 \mathrm{mbsf}) \\
9.74 \times 10^{7}\end{array}$ \\
\hline Approximately $80 \mathrm{mbsf}$ & $\begin{array}{c}(80.20 \text { mbsf }) \\
1.94 \times 10^{6}\end{array}$ & $\begin{array}{c}(78.89 \mathrm{mbsf}) \\
1.14 \times 10^{6}\end{array}$ & $\begin{array}{c}(81.60 \mathrm{mbsf}) \\
4.05 \times 10^{5}\end{array}$ \\
\hline Near-surface count $(\%)$ & $2.2 \%$ & $1.8 \%$ & $0.4 \%$ \\
\hline
\end{tabular}

Notes: Group A represents total counts, whereas Group B represents dividing cell counts. Bacterial data from Cragg et al. (1990, Leg 112) and Cragg et al. (1992, Leg 128). Oceanic productivity relationship from Berger (1989). Depth data from Suess, von Huene, et al. (1988, Leg 112); Ingle, Suyehiro, von Breymann, et al. (1990, Leg 128); Parson, Hawkins, Allan, et al. (1992, Leg 135), with 0 mbsf defined according to ODP.

the near-surface to approximately $2.4 \mathrm{mM}$ at $42 \mathrm{mbsf}$, a concentration that was then maintained to below 104.4 mbsf (Parson, Hawkins, Allan, et al., 1992). This suggests that bacterial activities were negligible over the entire depth of the hole, which is consistent with the very low organic carbon values. Despite this being a downwelling area, it is thought that the flow of bottom water is low enough not to affect the scatter of the minor element concentrations in the interstitial water resulting from interstitial water-mineral interactions (Parson, Hawkins, Allan, et al., 1992), and this appears to rule out low rates of sulfate reduction supported by a continual replacement of sulfate from the bottom water. Previous studies (Cragg et al., 1990, 1992; Parkes et al., 1990) have demonstrated a good correlation between microbial parameters, including total counts and geochemical data. Therefore, no reason exists to suggest that the microscopic determination of bacterial populations in Lau Basin sediments is not a realistic measure of the in-situ population. The absence of coarse-scale geochemical gradients with depth is consistent with very low bacterial biomass and activities. They may have been detected with finer resolution pore-water measurements, or their absence may reflect microbial activity other than sulfate reduction or methanogenesis. Conversely, the very small downward flow of bottom water may be sufficient to totally mask interstitial water changes associated with the very low rates of microbial activity that are likely.

\section{SUMMARY}

This data set is notable in that it represents a linear series of samples to as deep as 104 mbsf. This has allowed a great deal of relatively detailed information to be gathered from subsurface sediment layers. Many workers have focused their investigations on the sediment nearsurface where bacterial numbers and activities are generally maximal (Jørgensen et al., 1990). Others have performed a logarithmic series of samples to greater depths (Cragg et al., 1990, 1992; Parkes et al., 1990), which concentrates sampling in the upper layers and produces deeper subsurface samples often many tens of meters apart.

The sediment samples studied have a bacterial depth-profile consistent with a low organic carbon environment. Near-surface total counts are lower than those from more productive areas and decrease much more rapidly with depth. Numbers of dividing cells also decrease more rapidly with depth. The decreases in both the bacterial 
counts follow two distinct phases: initially, a rapid decline from the near-surface to approximately $20 \mathrm{mbsf}$, then a more gradual decline to 104.4 mbsf. Inorganic chemical data and organic carbon concentrations indirectly suggest that bacterial activity such as sulfate reduction and methanogenesis are extremely low. The apparent nonutilization of terminal electron acceptors such as sulfate, combined with low organic carbon concentrations, suggests that the bacteria in this sediment are in an extreme low-energy environment. This is consistent with a relatively low bacterial population that decreases rapidly with increasing sediment depth; however, it is particularly interesting that significant populations of bacteria exist at all in such an impoverished environment.

\section{ACKNOWLEDGMENTS}

I thank Peter Clift for sample collection, and R. John Parkes for constructive comments on the manuscript. This work was funded by a Special Topics research grant (GST/F90/2) while I was in possession of a Research Fellowship from the Natural Environment Research Council, United Kingdom. I acknowledge the support and facilities provided by Bristol University, and I am grateful to the Ocean Drilling Program for supplying samples from Leg 135.

\section{REFERENCES ${ }^{*}$}

Balkwill, D.L., 1989. Numbers, diversity and morphological characteristics of aerobic chemoheterotrophic bacteria in deep subsurface sediments from a site in South Carolina. Geomicrobiol. J., 7:33-52.

Belyaev, S.S., and Ivanov, M.V., 1983. Bacterial methanogenesis in underground waters. Environ. Geochem. Ecol. Bull., 35:273-280.

Berger, W.H., 1989. Global maps of ocean productivity. In Berger, W.H., Smetacek, V.S., and Wefer, G. (Eds.), Productivity of the Oceans: Present and Past: New York (Wiley), 429-455.

Bianchi, A., 1986. Heterotrophic bacterial types surviving in the Quaternary and upper Pliocene sediments of the Mahakam Delta. C.R. Acad. Sci., Ser. 3, 303:449-451.

Chapelle, F.H., and Lovley, D.R., 1990. Rates of microbial metabolism in deep coastal plain aquifers. Appl. Environ. Microbiol., 56:1865-1874.

Cragg, B.A., Harvey, S.M., Fry, J.C., Herbert, R.A., and Parkes, R.J., 1992. Bacterial biomass and activity in the deep sediment layers of the Japan Sea, Hole 798B. In Pisciotto, K.A., Ingle, J.C., Jr., von Breymann, M.T., Barron, J., et al., Proc. ODP, Sci. Results., 127/128 (Pt. 1): College Station, TX (Ocean Drilling Program), 761-776.

Cragg, B.A., Parkes, R.J., Fry, J.C., Herbert, R.A., Wimpenny, J.W.T., and Getliff, J.M., 1990. Bacterial biomass and activity profiles within deep sediment layers. In Suess, E., von Huene, R., et al., Proc. ODP, Sci. Results, 112: College Station, TX (Ocean Drilling Program), 607-619.

Davis, J.B., 1967. Petroleum Microbiology: Amsterdam (Elsevier).

Erlich, H.L., and Ghiorse, W.C. (Eds.), 1989. Deep Subsurface Microbiology. Geomicrobiol. J., Spec. Iss., 7.

Fredrickson, J.K., Balkwill, D.L., Zachara, J.M., Shu-Mei, W. Li, Brockman, F.J., and Simmons, M.A., 1991. Physiological diversity and distributions of heterotrophic bacteria in deep Cretaceous sediments of the Atlantic coastal plain. Appl. Environ. Microbiol., 57:402-411.

Fry, J.C., 1988. Determination of biomass. In Austin, B. (Ed.), Methods in Aquatic Bacteriology: Chichester (Wiley), 27-72.

Getliff, J.M., Fry, J.C., Cragg, B.A., and Parkes, R.J., 1992. The potential for bacteria growth in deep sediment layers of the Japan Sea, Hole 798B-Leg 128. In Pisciotto, K.A., Ingle, J.C., Jr., von Breymann, M.T., Barron, J., et al., Proc. ODP, Sci. Results., 127/128 (Pt. 1): College Station, TX (Ocean Drilling Program), 755-760.

Gooday, A.J., and Turley, C.M., 1990. Responses by benthic organisms to input of organic material to the ocean floor: a review. Philos. Trans R. Soc. London A, 331:119-138.

Goulder, R., 1977. Attached and free bacteria in an estuary with abundant suspended solids. J. Appl. Bacteriol., 43:399-405.
Ingle, J.C., Jr., Suyehiro, K., von Breymann, M.T., et al., 1990. Proc. ODP, Init. Repts., 128: College Station, TX (Ocean Drilling Program).

Jannasch, H.W., and Taylor, C.D., 1984. Deep-sea microbiology. Annu. Rev. Microbiol., 38:487-514.

Jørgensen, B.B., 1983. Processes at the sediment/water interface. In Bolin, B., and Cook, R.B. (Eds.), The Major Biogeochemical Cycles and Their Interactions: Chichester (Wiley), 477-515.

Jørgensen, B.B., Bang, M., and Blackburn, T.H., 1990. Anaerobic mineralization in marine sediments from the Baltic Sea-North Sea transition. Mar. Ecol. Prog. Ser., 59:39-54.

Kirchman, D., Sigda, J., Kapuscinski, R., and Mitchell, R., 1982. Statistical analysis of the direct count method for enumerating bacteria. Appl. Environ. Microbiol., 44:376-382.

Krumbein, W.E., 1983. Microbial Geochemistry: Oxford (Blackwell Sci.).

Oremland, R.S., Culbertson, C., and Simoneit, B.R.T., 1982. Methanogenic activity in sediment from Leg 64, Gulf of California. In Curray, J.R., Moore, D.G., et al., Init. Repts. DSDP, 64: Washington (U.S. Govt. Printing Office), 759-762.

Parkes, R.J., and Buckingham, W.J., 1986. The flow of organic carbon through aerobic respiration and sulfate reduction in inshore marine sediments. In Megusar, F., and Gantar, M. (Eds.), Proc. 4th Int. Symp. Microbial Ecol., $617-624$.

Parkes, R.J., Cragg, B.A., Fry, J.C., Herbert, R.A., and Wimpenny, J.W.T., 1990. Bacterial biomass and activity in deep sediment layers from the Peru margin. Philos. Trans. R. Soc. London A, 331:139-153.

Parson, L., Hawkins, J., Allan, J., et al., 1992. Proc. ODP, Init. Repts., 135: College Station, TX (Ocean Drilling Program).

Phelps, T.J., Fliermans, C.B., Garland, T.R., Pfiffner, S.M., and White, D.C., 1989. Methods for recovery of deep terrestrial subsurface sediments for microbiological studies. J. Microbiol. Methods, 9:267-279.

Rittenberg, S.C., 1940. Bacteriological analysis of some long cores of marine sediments. J. Mar. Res., 3:191-201.

Sørensen, J., 1978. Denitrification rates in marine sediment as measured by the acetylene inhibition technique. Appl. Environ. Microbiol., 36:139-143.

Sørensen, J., and Jørgensen, B.B., 1987. Early diagenesis in sediments from Danish coastal waters: microbial activity and $\mathrm{Mn}-\mathrm{Fe}-\mathrm{S}$ geochemistry. Geochim. Cosmochim. Acta, 51:1583-1590.

Suess, E., von Huene, R., et al., 1988. Proc. ODP, Init. Repts., 112: College Station, TX (Ocean Drilling Program).

Tarafa, M.E., Whelan, J.K., Oremland, R.S., and Smith, R.L., 1987. Evidence for microbiological activity in Leg 95 (New Jersey Transect) sediments. In Poag, C.W., Watts, A.B., et al., Init. Repts. DSDP, 95: Washington (U.S. Govt. Printing Office), 635-640.

ten Haven, H.L., Littke, R., Rullkötter, J., Stein, R., and Welte, D.H., 1990. Accumulation rates and composition of organic matter in late Cenozoic sediments underlying the active upwelling area off Peru. In Suess, E., von Huene, R., et al., Proc. ODP, Sci. Results, 112: College Station, TX (Ocean Drilling Program), 591-606.

Turley, C.M., and Lochte, K., 1990. Microbial responses to the input of fresh detritus to the deep-sea bed. Palaeogeogr., Palaeoclimatol., Palaeoecol., B9:3-23.

Whelan, J.K., Oremland, R., Tarafa, M., Smith, R., Howarth, R., and Lee, C., 1985. Evidence for sulfate-reducing and methane producing organisms in sediments from Sites 618, 619, and 622. In Bouma, A.H., Coleman, J.M., Meyer, A.W., et al., Init. Repts. DSDP, 96: Washington (U.S. Govt. Printing Office), 767-775.

White, D.C., Fredrickson, H.F., Gehron, M.H., Smith, G.A., and Martz, R.F., 1983. The groundwater aquifer microbiota: biomass, community structure and nutritional status. Dev. Ind. Microbiol., 24:189-199.

ZoBell, C.E., 1958. Ecology of sulfate reducing bacteria. Prod. Mon., 22:12-29. Abbreviations for names of organizations and publication titles in ODP reference lists
follow the style given in Chemical Abstracts Service Source Index (published by
American Chemical Society).

Date of initial receipt: 25 June 1992

Date of acceptance: 30 October 1992

Ms 135SR-106 